\title{
Equality as a Theological Principle within Roman Catholic Ecclesiology
}

\author{
Thomas O'Loughlin \\ Professor Emeritus of Historical Theology, Department of Theology and \\ Religious Studies, University of Nottingham, Nottingham, UK \\ Thomas.Oloughlin@nottingham.ac.uk
}

\begin{abstract}
As the Roman Catholic Church aspires 'to embrace a synodal way', some old questions about its ecclesial vision return. One such question is the equality of all the baptised within the church. This question is particularly fraught because of the church's long history of viewing the itself as a society of unequals, its hierarchical structures, and its culture of top-down authority modelled on pre-modern monarchical conceptions of society. This paper argues that not only must the church face the implications of accepting the equality of the baptised as a basis of its praxis, but also that it should embrace that equality as part of its witness and service to the world. Thus, it must not simply take equality to heart and express it in its rituals, but must create a 'theology of human equality' which then becomes part of its preaching.
\end{abstract}

\section{Keywords}

baptism - episcopacy - equality - gender - hierarchy - laity - Roman Catholic Church - synodality

\section{Introduction}

Not so long ago Roman Catholics openly declared themselves to belong to a church of unequals. Not only was the church a society of unequals, but that very inequality (arising from its having those among it with the so-called 'powers' of 'order' and of 'jurisdiction') was part of its perfection - and that it was a 
societas perfecta was commonly seen as a matter of faith. ${ }^{1}$ This claim has cast a long shadow over the Roman Catholic Church because all too often there was an implicit alliance between the church and others, such as the great landowners in places like Spain or South America or with regimes in 'Catholic' countries, for mutual support. ${ }^{2}$ The 'altar' supported the 'crown' and vice versa, and bishops, accustomed to being addressed with feudal deference, appeared as flanking supports in those states' displays of power. ${ }^{3}$ This shadow is still present in Roman Catholic theology: that famous phrase societas perfecta et inaequalium is cited in the 2018 document from the International Theological Commission entitled: Synodality in the Life and Mission of the Church. There it is not dismissed as down-right wrong, but side-stepped as an exaggeration - its context being its justification: 'an apologetic reaction to the Protestant Reformation's criticism of ecclesiastical authority'. We may live in a world where 'equality' has been a favourite political slogan since 1789, but for many in the Roman Catholic Church it is still somehow problematic. This discomfort arises because the ideal of equality has to be accommodated to the teaching that the ministry of priests ${ }^{5}$ is different in nature and not only in degree from that of the rest of the baptised; that the powers and authority of bishops come directly from the apostles and not from those whom they 'govern'; 6 and

1 This can be found in any neo-scholastic manual; for example: Michaele Nicolau and Joachim Salaverri, Sacrae theologiae summa (Madrid: Biblioteca Autores Cristianos, 1952), vol. 1, p. 826.

2 A very instructive account of such linking of authority structures, and how this was questioned in the years following the Second Vatican Council (1962-65), can be found in Eugenia Relaño Pastor, 'Spanish Catholic Church in Franco Regime: A marriage of convenience', Kirchliche Zeitgeschichte 20 (2007), pp. 275-287.

3 See Sidney Z. Ehler and John B. Morrall (eds), Church and State Through the Centuries: A Collection of Historic Documents with Commentaries (London: Burns \& Oates, 1954), pp. 234-617 (documents from 1790 to 1949).

4 International Theological Commission, Synodality in the Life and Mission of the Church [2 March 2018], § 35. The document can be found at: https://www.vatican.va/roman_curia/ congregations/cfaith/cti_documents/rc_cti_20180302_sinodalita_en.html (accessed 10 June 2021).

5 I am using 'priests' here in the sense that sacerdotes (i.e. presbyters and bishops) is used in the 1983 Code of Canon Law; meaning those who have the sacramental 'powers' (see Lumen Gentium, § 10) to preside at the Eucharist and to absolve sinners in the Sacrament of Reconciliation.

6 See, for example, Adolph Tanquerey, Brevior Synopsis Theologiae Dogmaticae, gth edn (Paris: Desclée, 1949), p. 97: Christus Ecclesiam ut societatem hierarchicam instituit Apostolis conferendo triplicem potestatem docendi, regendi, et sanctificandifideles (Christ instituted as a hierarchical [and from p. 96 it is clear that this is the opposite of a 'democratic'] society conferring on the Apostles the three-fold power of teaching, ruling over, and sanctifying the faithful ones). Quoting such a brief guide is a better indicator of what was actually taught and widely held than can be obtained by quoting some of the more skilled and nuanced theologians of the day. 
especially that the authority of the Bishop of Rome is unique - even alongside other patriarchs he cannot simply be viewed as primus inter pares - for his authority is presented as the result of action of Christ specifically authorising Peter (Matt. 16:18). One disturbing feature of many recent documents emanating from the Vatican, for example Synodality in the Life and Mission of the Church, is that no consistent hermeneutic of texts relating to authority is discernible. The appeal to the 'Council of Jerusalem' is a case in point: at the first mention $(\S 20)$, it is referred to with a little circumspection as 'what has been called 'the Council ...' and the reference is given as 'cf. Acts 15 and also Gal. 2:1-10' without comment. By the time we reach $\S 22$, this council is a simple fact of early church history, while by $\S 42$ it is not merely a fact but has an 'exemplary and normative character'. A guide to the Commission's reading strategy and to their position vis-à-vis the normal methods of historians, would produce a more coherent discussion. ${ }^{7}$

This issue of equality and inequality is sometimes imagined as having been resolved in the Second Vatican Council (1962-65) in that it did not use the notion of a societas perfecta so common in writing on ecclesiology until the 1950s. However, Vatican II did not so much address the societal model - and so the issue of equality - as replace it with a sacramental approach to the church. ${ }^{8}$ While it is true that in this latter approach the dignity of each of the baptised as part of the priestly People of God becomes central - and so an implicit statement of equality in baptism - it had to be balanced by what was said in the decree Presbyterorum ordinis (1965) with its re-iteration of the significance of 'the sacred power of Order' and that 'special character' such that the ordained 'are configured to Christ the priest in such a way that they are able to act in the person of Christ the head.9 The distinctiveness of those in Holy Order, the clergy, is presented analogically in reference to head to body (the classic 'Pauline' image): ${ }^{10}$ Christ and the church, the Twelve and the other disciples. ${ }^{11}$

Lumen Gentium can be seen as an attempt to hold the notion of equality and that of specific special ministerial identity and status together, without

7 The traditional appeal to 'the Petrine text.' On the implications of not methodically separating historical and theological approaches - and then letting them become confused - see Paul Avis, 'Editorial: The Paschal Mystery and the Church', Ecclesiology 17 (2021), pp. 3-6.

8 See Patrick Granfield, 'The Church as Societas Perfecta in the Schemata of Vatican I', Church History 48.4 (1979), pp. 431-446.

9 Presbyterorum ordinis, § 2.

10 See Eph. 4:15 and 5:23.

11 These distinctions are used as simple binaries - a more nuanced usage is not only needed but would alert all to 'appeals to origins'. 
acknowledging that that there is an internal contradiction between these notions. ${ }^{12}$ Lumen Gentium, § 10 reads: 'Though they differ essentially and not only in degree [my emphasis], the common priesthood of the faithful and the ministerial or hierarchical priesthood are none the less ordered to one another ... [t] he ministerial priest, by the sacred power that he has, forms and rules the priestly people.' While many commentators have emphasised that this statement should not be understood in terms of a pyramid of power - and so of inequality - but in terms of common equality of baptism..$^{13}$ However, there is consistent opposition to such 'equalizing' interpretations, and these voices have become more strident within Roman Catholicism in recent decades. ${ }^{14}$ Moreover, this interpretation assumes that equality is achieved in the mutual relationship of these two groups. But this is not how it is experienced in actual Roman Catholic communities, be they parishes or dioceses, and it fails to acknowledge that this is simply an analogue of the manifestly unequal distinction of officers versus 'other ranks' that is used in the military. The fudge is similar to the famous cry in George Orwell's Animal Farm, so: 'All the baptised are equal but some of the baptised are more equal than others.'

This attempt to square the circle of all Christians being called to ministry, but also affirming the distinctiveness of those who, as priests, have a unique potentia and character in relation to others in terms of sanctifying, teaching and ruling, can be found in any number of official documents from the Vatican since the mid-196os. ${ }^{15}$ In the recent report ahead of the 2023 Synod of Bishops, it could be said to be the tension that is present between every pair of paragraphs. Reading it is like watching a pendulum swing between synodal church and a clergy versus laity church; or the priest is one of the baptised versus the priest is distinctive among the baptised; or all voices should be heard versus

12 In this perception of the 'special place' of the ordained, it is possible that the 'nontheological factors' outweigh those which arise from a study of the Scriptures or ecclesiology. The dominant factor is more likely to be the sense of being a spiritual elite who have been specially 'formed' as such in seminaries where imparting an esprit de corps of priests as mediators of the divine and as the special 'intimates' of Jesus to a passive / receptive laity was central. The key work exploring this is Clare McGrath-Merkle, Bérulle's Spiritual Theology of Priesthood: A Study in Speculative Mysticism and Applied Metaphysics (Münster: Aschendorff, 2018).

13 For example: Philip J. Rosato, 'Priesthood of the Baptized and Priesthood of the Ordained: Complementary Approaches to their Interpretation', Gregorianum 68 (1987), pp. 215-266.

14 For example: Gustave Martelet, Deux mille ans d'église en question: Théologie du Sacerdoce (Paris: Cerf, 1984), vol. 1: Crise de la foi, crise du prêtre, pp. 99-121.

15 Cf. Roger W. Nutt, 'Sacerdotal Character and the "Munera Christi": Reflections on the Theology [of] Charles Journey in Relation to the Second Vatican Council', Gregorianum go (2009), pp. 237-253. 
episcopal voices should be specially heard; or all pastors share the care of the flock versus all pastors must acknowledge the unique ministry of the Bishop of Rome. While little theological skill is required to justify each of these distinctions, all such explanations have the character of special pleading. Moreover, if the Roman Catholic Church is now being called to move towards a 'synodal church' and to follow Pope Francis 'on a synodal way', it seems that defending these distinctions is little more than a defence of the status quo ante. It might be better for all concerned to begin by acknowledging that this was one of the many issues left unresolved when the council ended, and one that is part of the larger endeavour of the Roman Catholic Church to come to grips with a modernity in which the paradigm of political organisation is democracy rather than monarchy. This does not mean that the ideal of equality is a loose end that now needs to be tidied up and neatly packed away, but rather that it was a seed, pregnant with possibilities, that was sown by the council and which has now grown and is today such a significant plant in our landscape that we must now give it the notice it deserves.

\section{Re-framing the Question.}

Since the later Middle Ages this debate has been framed in terms of the power of order (potestas ordinis), its indefectibility (whether sacramental validity is ex opere operato), and the right of its possessors to govern (dominium). The debate emerged with John Wycliffe and the Conciliarists and came to a head in the early years of the sixteenth century when these questions were central to the theology of the Reformers, and it was the form in which that theology was rejected by the Council of Trent that has determined the shape of Roman Catholic debates since then. Here the starting point is with the group who can be referred to as the sacerdotes, and how that group relates to a larger set, the Christifideles. ${ }^{16}$ There are two weaknesses with this starting point. The first is sociological: it assumes that the clergy form an obvious, numerous and clearly perceived group within a larger society where their distinctiveness - in terms of what they do that others do not do - is as much a fact of experience as taxes, motor cars or telephones. In this world the king rules, the soldier fights and the parochus prays - and the debate regulates the latter's rights and duties in relation to the others. It is this notion that underlies much Roman

16 Cf. Thomas O'Loughlin, 'Sacramental Languages and Intercommunion: identifying a source of tension between the Catholic and the Reformed churches', Studia Liturgica 47 (2017), pp. 138-150. 
Catholic thinking on 'the laity' even today as a legacy from how the debate was prosecuted for centuries as about the rights and role of the clergy in the state, presented as the 'church-state' debate, as can be seen in many languages where 'the role of the church' is imagined in terms of clerical power or the absence of an established religion is seen as the state being 'lay'. ${ }^{17}$ While this might be seen as merely an historical point when we look around Europe today, this notion is still pervasive within the concept of the special formation envisaged in the current ratio fundamentalis of the Roman Catholic Church for its seminaries. ${ }^{18}$ Such a clerical society may still exist in isolated bubbles, but the debate is now far wider, involving many of the baptised who are not clergy (widespread literacy, including theological literacy, has undermined a key distinguishing feature of the 'Clerk in Holy Orders') but also narrower because we live in a secular, multicultural world. Second, the starting point begs the question of what underlies the distinction: it seems that one must either uphold the notion of the special status of the ordained or deny it. ${ }^{19}$ It is a zero-sum game.

The alternative starting point is the equality of the baptised, and how each individual Christian relates to those around her/him in the actual community in which they live, and so, by extension, in the universal church. The event of baptism across the all the churches is, moreover, the only starting point for any discussion of equality within ecumenical dialogue. If we do not have equality in baptism, then all dialogue between churches is no more than diplomacy between contending powers - as can be seen in the presentation of baptism in the World Council of Churches' Lima document of 1982, Baptism, Eucharist and Ministry. ${ }^{20}$ So, should we make this the starting point for understanding relationships - a fundamental component of those relationships - in a synodal church? There are several advantages to embarking on a study of ecclesiology with 'equality' as the common ground between the investigators. For a start, in contemporary society it is seen as a human good - that which we should all

17 For example, the notion of laïcité in France; cf. https://www.gouvernement.fr/qu-est-ce-quela-laicite (accessed 14 June 2021).

18 See Congregation for the Clergy, Il Dono della vocazione presbiterale: Ratio Fundamentalis Institutionis Sacerdotalis (Rome: L'Osservatore Romano, 2016).

19 The Roman document of 2016 mentioned in the previous note is a very good example of this petitio principii - it presents this ministry as a specific and distinguishing divine gift without ever asking whether that is how vocation should be considered among Christians.

20 Baptism, Eucharist and Ministry, Faith and Order Paper 111 (Geneva: World Council of Churches, 1982). On the significance of its approach to baptism, see Thomas O'Loughlin, 'From Warrant to Imagination: An Un-Noticed Aspect of BEM', One in Christ 54.2 (2020), pp. 166-179. 
embrace and affirm. It is, at least in democratic societies, one of the few pieces of common ethical currency - and in so far as it is a humanly affirmed good, it forms a basis by which any ecclesial discussion can be seen as an example of grace building upon, rather than running counter to, nature. ${ }^{21}$

The notion of equality is usually traced to the French Revolution and, more broadly, to the Enlightenment - a damning pedigree for many traditionalist Roman Catholics - but it is arguable that the vision of every human being equal has its deep roots, if tangled ones, in the tradition of Christian law and ethics. However, the status of equality as a self-evident good (bonum per se notum) is most often asserted not by appeal to a principle, ${ }^{22}$ but by the rejection of its converse. Any act of inequality - for instance in the treatment of workers, those waiting for medical assistance, or housing - is seen as an affront and an act of injustice that needs to be remedied. Any group which rejects the equality principle as expressed in democracy is rejected. This is not merely an intellectual rejection, but a visceral detestation of that which prevents humans expressing their equality and with it their rights. Whether it is military repression in Myanmar or bishops in Franco's entourage, even the images of such inequality insult and embarrass us. Likewise, it is taken for granted that slavery and the slave trade is utterly evil, incompatible with the basic fact of human equality, and, today, this is a basic part of the Christian ethical vision. ${ }^{23}$ The notion that slavery is immoral is now part of the discourse of popes and bishops. ${ }^{24}$ Such an embrace of the notion of equality as to condemn slavery as immoral is as significant a departure from long standing practice as

21 The notion that there should be a coherence and a continuity between the observable created order and the revealed order of grace is a principle appealed to frequently in Roman Catholic discourse. The locus classicus for this approach is usually presented as 'gratia non tollit naturam sed perficit' (Thomas Aquinas, Summa Theologiae 1, 1, 8, ad 2), but in the present context Aquinas's other formulation of this notion of grace as perfectio naturae rationalis creatae (Quaestiones Quodlibetales, 4, 6) may be more apposite: equality, already existing as a morally good quality in some human societies, is seen most perfectly when it becomes a theological principle animating the relationships within the whole church.

The notion that it is self-evident (per se notum) that humans are equal is, to my knowledge, first found in the American Declaration of Independence (1 July 1776): 'We hold these truths to be self-evident, that all men are created equal, that they are endowed by their Creator with certain unalienable Rights, that among these are Life, Liberty and the pursuit of Happiness.' (https://www.archives.gov/founding-docs/declaration-transcript (accessed 13 June 2021).

23 See, for example, Jennifer A. Glancy, Slavery as Moral Problem: in the Early Church and Today (Minneapolis: Fortress Press, 2011).

24 See The Catechism of the Catholic Church, 2nd edn (Rome: Libreria Editrice Vaticana, 2019 [1st edn 1994]), § 2414. This document sees slavery as contrary to a commandment of the Decalogue and as not admitting exceptions, citing Philem. 16 in support. 
can be imagined. Augustine of Hippo owned slaves in the fifth century; ${ }^{25}$ and as recently as 186o moral theology textbooks for use in American seminaries defended the legitimacy of slavery. ${ }^{26}$ Indeed, the Roman Catholic Church was notably absent from the abolitionist movement. ${ }^{27}$ The contemporary stance on slavery is surely one of the most significant examples of the development of doctrine in modern times and suggests that a trend is already at work within Roman Catholicism that points towards embracing equality more fully within its theological landscape. However, it would be naïve to imagine that Roman Catholicism, whose clerical social rituals have been deeply enmeshed with the courtesies of ancien régime Europe, has yet taken seriously how its projection of itself globally - any published image will show careful distinctions of rank and authority though location and uniform - needs to embrace an actual, practical culture that maintains that the equality of the baptised in Christ is part of its core message. It not only needs to acknowledge equality but to appear to take equality seriously for in projecting its image it is engaging in an act of communication and so preaching its message.

Equality is also fundamental to a vision of a world order based on law and democratic institutions. While some post-modern writers like to point out the cultural specificity of the notion of democracy, it remains (to assert the very minimum) the least-worst system, has contributed to the maintenance of international peace, and its elementary assumption is the equality of individuals at the ballot box. Equality is, thus, not only a civil right, but a basic human right - a fact affirmed positively in that it is one of the UN's 17 sustainable

25 See, e.g., De civitate Dei 19,15-16, or 22,22; and the study by Gervase Corcoran, Saint Augustine on Slavery (Rome: Institutum Patristicum Augustinianum, 1985). A list of early Christian writers who make passing references to their owning slaves would be a very long one. See Peter Garnsey, Ideas of Slavery from Aristotle to Augustine (Cambridge: Cambridge University Press, 1996); and Ronald Charles, The Silencing of the Slaves in Early Jewish and Christians Texts (London: Routledge, 2019). Explanations of slavery as simply part of the disposition of nature are easily found, e.g., Pope Gregory the Great, Moralia in Iob 21,14,15.

26 See the treatment in Archbishop Francis Patrick Kenrick, Theologia Moralis (Mechelen: Dessain, 186o [1st edn 1841]), Tract 5 , Ch. 6 (De servitute), nn. 35-41 (vol. 1, pp. 164-8). On the ownership of slaves by Roman Catholic religious orders in the United States, see Thomas J. Murphy, Jesuit Slaveholding in Maryland, 1717-1838 (New York: Routledge, 2001).

27 In an egregious instance of bigoted gallows taunting, a Roman Catholic priest visited John Brown on the eve of his execution in 1859 and teased him about his views on slavery which this priest took as acceptable on the basis that it was approved by St Paul (see James W. Ely, Jnr, and Daniel P. Jordan, 'Harpers Ferry Revisited: Father Costelloe's "Short Sketch" of Brown's Raid', Records of the American Catholic Historical Society 85 (1974), pp. 59-67). In 2020 a university in the United States removed the name of the first Roman Catholic bishop (Matthias Loras) in Dubuque, Iowa, when it emerged that he had been a slave owner, see 
development goals, ${ }^{28}$ and affirmed negatively in that it is the absence of equality of treatment that lies at the basis of most movements that call for reform within our society (currently 'Black Lives Matter'). By contrast, studies of slavery typically refer to the intrinsic links between slavery, racism, colonialism, the limited roles of women in society (i.e., gender inequality) and hierarchical views of human society. ${ }^{29}$ So one either accepts that equality is an expanding human right or one finds oneself defending the indefensible - and the 2023 Synod of Bishops in Rome may be the moment of decision for the Roman Catholic Church. In short, the equality of all - a notion alien to most of the writers and authorities within our intellectual history ${ }^{30}$ - is now a welcome, if challenging, part of our ethical landscape.$^{31}$ For the Roman Catholic Church not to embrace it as a good would not only be a creation-denying exceptionalism, but possibly also an 'aeonal sin' in its failure to see the Holy Spirit at work in human hearts. ${ }^{32}$

\section{Forms of Equality}

If equality is to be affirmed as a positive component in our ecclesiology, then we might note that it is a polyvalent notion which makes differing levels of demand on us. Equality is a many-faceted reality, and a failure to take account of this can itself be a source of inequality. Perhaps the simplest form of equality - though it is by no means common - is that of equality before the law: no

https://www.twincities.com/2020/og/22/st-thomas-convenes-group-on-renamings-afterlearning-namesake-bishop-owned-slave/ (accessed 10 June 2021).

28 For information on the Sustainable Development Goals see https://sdgs.un.org/goals.

29 See, e.g., Paul Millett, 'Aristotle and Slavery in Athens', Greece \& Rome 54.2 (2007), pp. 178-209. Making the same connections but in a very different way, linking slavery with inequality in ethnicity, gender and sexuality, is Jennifer A. Glancy, 'Slavery in Acts of Thomas', Journal of Early Christian History 2.2 (2012), pp. 3-21.

30 One need only recall Aristotle's comments in the first book of the Politics (e.g. 1,5 on the rationality of slaves (1254b)); or the famous comment of Karl Marx: 'The social principles of Christianity justified the slavery of Antiquity, glorified the serfdom of the Middle Ages and equally know, when necessary, how to defend the oppression of the proletariat, although they make pitiful face over it': 'The Communism of the Paper Rheinischer Beobachter' [1847] as found in Karl Marx and Frederick Engels, On Religion (Moscow: Progress Publishers, 1957), p. 74.

31 The presence in organisations (from governments to universities to business corporations) of codes of conduct to eliminate bias and provide a 'level playing field' are a concrete embodiment of this awareness of the place of equality in human interactions in society. 
matter how high you are, the law is higher. ${ }^{33}$ It is the vision of any number of legal systems that, whether prince or commoner, the law applies equally to each. We take this for granted, but it has been a hard-fought right for those of us who enjoy it. Surprisingly, it was a notion opposed by the Church until well into the twentieth century in its claims for clergy to enjoy the privilegium fori ${ }^{34}$ - and some suspect that it is a legacy of that thinking that induced many bishops to cover up clerical sexual abuse under the mistaken belief that canon law provided sufficient legal basis for their actions. Indeed, it was only in 2021 that Pope Francis removed the last traces of inequality in treatment in canon law. The motu proprio contains a very interesting comment on how the notion of equality is now part of our human inheritance: the pope wished 'to recall the "overriding need for the current procedural system - also by means of appropriate changes in the law - to ensure the equality of all members of the church in their equal dignity and position, without privileges that date back to earlier times and are no longer in keeping with the responsibilities that each person has in building up the church.'35 The notion of an evolution of rights is linked not only to a greater sense of equality in human dignity, but to a deepening awareness of what it to be a member of the Church.

Legal equality is often justified by an appeal to (a) its being grounded in the fact of our human equality: we are born free; and (b) every human being born on this planet has as much right to life and the good things of life as any other. Almost by reflex, most Christians when presented with this scenario will affirm the equality of every human. For example, a group shown photographs, sideby-side, of a baby in a London hospital and of another baby in a dilapidated hospital in the Global South, and presented with the question: 'have these children equal dignity as inhabitants of this planet?' But before we congratulate ourselves, ${ }^{36}$ we might note that this is the precise idea that was rejected by

33 To use the now famous formulation used by Lord Denning: 'To every subject of this land, however powerful, I would use Thomas Fuller's words over three hundred years ago, "Be ye never so high, the law is above you"': Susan Ratcliffe (ed.), Oxford Essential Quotations (Oxford: Oxford University Press, 2016); cited from the on-line edition at https://www. oxfordreference.com/view/10.1093/acref/9780191826719.001.ooo1/q-oro-ed4-oooo3551 (accessed 15 June 2021).

34 This was still part of the Vatican's arrangements with Spain until the early 1970s; see Relaño Pastor (2007) cited in n. 2 above.

35 The motu proprio of 30 April 2021 on 'Amending the Jurisdiction of the Judicial Bodies of the Vatican City State': http://www.vatican.va/content/francesco/en/motu_proprio/documents/ papa-francesco-motu-proprio-20210430_competenza-organigiudiziari.html (accessed 15 June 2021).

36 Moreover, before anything else they might note another inequality: the wealth of one group is directly linked to the poverty of the other group, see Rachel Jenkins, et al., 'International 
most classical writers on ethics and the human condition. Nothing seemed more 'natural' than that some were born to be slaves and some to be free, ${ }^{37}$ or to sing: "The rich man in his castle / The poor man at his gate / God made them high and lowly / And ordered their estate. ${ }^{38}$ The notion is still an implicit part of the cultural landscape in those countries which have hereditary monarchies. It is equally true that this notion is widely rejected on empirical grounds as utopian or fanciful by many economists and policy makers. To them, there is a fact that no two children have the same health and life-expectancy at birth - which is due both to their DNA and their situation; similarly in terms of ability - again due both to capability and access to education - or of economic potential, or, indeed, sheer luck. While this is a dismal vision, it does reveal just how counter-intuitive many of our Christian aspirations for a more just world are for many. In fact, the notion of égalité at birth is intimately linked to the notion - first formally expressed in the modern era in the eighteenth century - that humans have an innate liberty (liberté) and that on this basis they possess fraternité as sisters and brothers. This principle implicitly appeals to the notion that all off-spring should be considered equal (i.e., no primogeniture in titles or wealth). It is this vision that is considered axiomatic (per se notum) in the American Declaration of Independence: 'We hold these truths to be self-evident, that all men are created equal, that they are endowed by their Creator with certain inalienable rights, that among these are Life, Liberty and the pursuit of Happiness'; 39 in the motto of the French Republic; and in the aspiration of the Irish 1916 revolutionaries of 'cherishing all the children of the nation equally', having already made a claim for legal equality. ${ }^{40}$ Though we note that many of those who formulated the American Declaration were

Migration of Doctors, and Its Impact on Availability of Psychiatrists in Low and Middle Income Countries', PLoS ONE 5.2 (2010), e9o49. https://doi.org/10.1371/journal.pone.ooogo49 (accessed 15 June 20121).

37 Aristotle, Politics 1 (1254a, 14-54b, 23). There is a very convenient survey of Aristotle's views in Anthony Preus, 'Aristotle on Slavery: Recent Reactions', Philosophical Inquiry 15 (1993), pp. 33-47; and see Garnsey, Ideas of Slavery from Aristotle to Augustine, and Millett, 'Aristotle and Slavery in Athens.'

38 Cecil Frances Alexander's hymn 'All things bright and beautiful' from her collection Hymns for Little Children (London: J. Masters, 1848). Significantly, as early as 1906 when Percy Dearmer edited The English Hymnal (Oxford: Oxford University Press, 19o6) this verse was omitted as outdated.

39 See n. 20 above.

40 'The Proclamation of an Irish Republic' signed by the leaders of the 1916 rebellion in Ireland. The complete text is widely available on the internet; and for further information, see Liam De Paor, On the Easter Proclamation: And Other Declarations (Dublin: Four Courts Press, 1997). 
slave-owners and that slavery was part of the American constitution until 1865; privilege and inequality did not disappear from France on Bastille Day; and there was no re-distribution of resources in post-1921 Ireland. These examples remind us that equality is a moral ambition among humans rather than a sociological fact.

Among Christians there is a corresponding notion of equality based on every human being brought into existence by God's creative will; thus every human is a child of God. ${ }^{41}$ However, this notion of all being God's children - a Stoic notion used by Luke in Acts 17:28 so that Paul could establish a common ground with his audience ${ }^{42}$ - was rarely invoked to promote equality in Christian societies until the time of the Abolitionists in the later eighteenth century with their slogan, 'Am I not a man and a brother?'43 (this question has gained new currency in our own day in the ritual of 'taking the knee' in the Black Lives Matter movement). However, there is one notable exception to this neglect: Philo of Alexandria and what he tells us about Qumran. Philo adopted the stance that slavery was incompatible with belief in the God of Israel precisely because every human being is equally the child of God. ${ }^{44}$

41 Cf. 1 John 3:1 'See what love the Father has given us, that we should be called children of God; and so we are.' This notion has been used by several theologians to argue for gender and racial equality, see, for example, these two articles by Nichole M. Flores, 'Trinity and Justice: A Theological Response to the Sexual Assault of Migrant Women', Journal of Religion and Society 16.1 (2018), pp. 39-51, and 'Beyond Consumptive Solidarity: An Aesthetic Response to Human Trafficking', Journal of Religious Ethics 46.2 (2018), pp. 36o-377.

42 Luke attributes the line to 'your poets' and most editions (e.g., Nestle-Aland) then cite Aratus, Phaenomena 5 (cf. Robert Renehan, 'Acts 17.28', Greek, Roman, and Byzantine Studies 20.4 (2011), pp. 347-353); however, it would be more accurate to cite Cleanthes's Hymn to Zeus where it has formal poetic form: Are we not Thy offspring Taking the image only of Thy voice, As many mortal things as live and move upon the earth. This is the translation of Thomas William Rolleston, The teaching of Epictetus: being the 'Enchiridion of Epictetus,' with selections from the 'Dissertations' and 'Fragments' (London: Walter Scott, 1891), p. 2. This theme of the divine paternity in the time of Jesus is explored by Jeremy Corley, 'God as merciful father in Ben Sira and the New Testament' in Renata Egger-Wenzel (ed.), Ben Sira's God: Proceedings of the International Ben Sira Conference, Durham-Ushaw College (Berlin: De Gruyter, 2002), pp. 33-38.

43 Cf. Hugh Thomas, The Slave Trade: The History of the Atlantic Slave Trade: 1440-1870 (London: Simon and Schuster, 1997), pp. 465-483.

44 Philo, Quod omnis probus liber sit, trans. Francis Henry Colson (London: William Heinemann, 1985). There is a reference in the opening sentence of the work to another, now lost, treatise entitled 'That every bad man is a slave', which shows that it is a subject that was of concern to Philo. However, one must be careful not to see in Philo himself a modern advocate of equality ante nomen because his attitude towards slavery is practically accommodating: on the one hand he denied that any person is by nature a slave - a notion he links to the rest given to all by God on the Sabbath (De specialibus legibus 2, 69, in Francis Henry Colson 
Philo's theological insight was informed by the Stoics but he transforms it in terms of the relationship of humanity to the divine transcendence. He then portrayed the Essenes as not tolerating slavery for the very reason that every life is as much from God as the next (although whether or not the Qumran community did actually reject slavery is a matter of debate). ${ }^{45}$

Yet another approach to equality is that, whatever our different fortunes, we are equal in our end: mortality is the great leveller. This truth has often been the preferred notion of equality among Christians: God will regard all equally, level the scales, and give a just - by analogy with legal equity - judgement. It is a theme with deep roots in the Hebrew Bible (e.g., 2 Chr. 19:7 and Job 34:19) that 'God does not show partiality'. It was cited by Paul (Rom. 2:11 and Gal. 2:6) and in other early Christian texts (e.g., Eph. 6:9 and Col. 3:25). However, this does not take us far towards a vision of equality in our relationships and social structures. Indeed, it could be seen as an invitation to side-step that equality, which is such a deep human desire, on the basis that it can be postponed to the eschaton. Likewise, when this tactic has been cited in the past, it has often amounted to a statement that all humans are sinful, all will face a reckoning, and that it will be just. Such a judgement-based theology is questionable in itself, and quite useless in response to the human desire for the good of equality. To say, for example to the survivors of the Holocaust or to the relatives of George Floyd, that all humans are sinners and God will judge all with equal justice is not merely pious and trite nonsense, but blasphemous for it denies the divine call to share in building up the creation as the kingdom of justice, peace and love.

By far the most common forms of equality that we meet in our everyday lives are far closer to us as agents in society that the ideas that we have been examining. In most situations, equality takes the form of equality of opportunity and of mutuality between people in the same situation. If two people apply for a job, we desire them to be treated on their merits and equality means that we seek to exclude bias and prejudice. There is a deep sense of this kind of equality in the training we now receive in order to take part in appointment processes. We desire that people get equal consideration irrespective of gender, race, ethnicity, or sexual orientation - and we are often shocked when

trans. (London: William Heinemann, 1937), p. 350), but in the same work he also asserts that the law [Lev. 25:35-41] does permit the acquisition of slaves and recognises their importance for the economy (2, 123, pp. 378-381). See Peter Garnsey, 'Philo Judaeus and Slave Theory', Scripta Classica Israelica 13 (1994), pp. 30-45, who explores the ambiguities in Philo's position.

45 Cf. Alejandro J. Botta, 'Slaves, Slavery', in John J. Collins and Daniel C. Harlow (eds), The Eerdmans Dictionary of Early Judaism (Grand Rapids, MI: Eerdmanns, 2010), pp. 1232-1233. 
we discover just how deep seated our biases are which hinder our acting with equality. Likewise, we want young people to have equal access to education and we claim that we want equality in access to health care. This is the notion of equality that underpinned Martin Luther King's 'I have a dream' speech in Washington in August 1963 and Pope Francis's call on 8 May 2021 for vaccines against Covid-19 to be available to all; ${ }^{46}$ and in a more humdrum way when people waiting for a bus point out to a someone pushing past them, "There is a queue!' Rather disturbingly, in the face of calls for gender equality and equality with regard to sexual orientation, it is remarkable that some of the most strident voices of opposition come from among Christians, especially Roman Catholics, claiming exemptions from this or that aspect of equality legislation. ${ }^{47}$ There is often a failure to appreciate that rights generate rights: one form of equality leads to the recognition that there is another area where equality should be sought. In this situation, unless there are the most compelling reasons, there is the danger that opposition to equality is the opening move in an unravelling of an edifice of rights. Just as rights lead to rights, so it is usually the unravelling of one right that leads to the curtailment of the next.

\section{A Christian Notion of Equality}

Is there a specifically Christian notion of equality that is more than a general ethical sanctioning that human equality is a good thing, and so, by implication, a goal for Christians? An obvious starting point is that the whole tradition of a Christian ethics is founded in the summation of the earthly demands upon Jesus' disciples: 'You shall love your neighbour as yourself.'48 The supposition is that I and every other person are interchangeable in respect of our duties towards one another: neighbours are equal. However, we can see other equalities in our fundamental Christian vision. We enter into a covenant relationship with God through baptism into Christ. We are equal in baptism, the fundamental constitutive event of the church. However, for many Christians this baptismal equality is less obvious than the experience of a layered community and

46 Available at: http://www.vatican.va/content/francesco/en/events/event.dir.html/content/ vaticanevents/en/2021/5/8/videomessaggio-vaxlive.html (accessed 1 June 2021).

47 This is very often seen in relation to equal employment rights regardless of sexual orientation where churches claim exemptions on the basis of the religious positions or sensibilities. The complexity of this area can be assessed in Stephen Hunt, 'Negotiating Equality in the Equality Act of 2010 (United Kingdom): Church-State Relations in a Post-Christian Society', Journal of Church and State $55 \cdot 4$ (2013), pp. 69o-711.

Matt. 19:19 and 22:39, and parallels. 
hierarchy. This phenomenon must not go unchallenged; deepening our understanding of our equality in baptism is central to deepening our ecclesiology. The Christians are the baptised, and later specialist tasks such as deacon, presbyter or bishop do not make one any more a member of the church than baptism does. However, in practice these distinctions do foster theoretical and practical inequality. This levelling aspect of baptism has always created tensions with the notion of a 'gentry class' - the literal meaning of ordo - within the churches that evolved in the fourth century. ${ }^{49}$ The stratified church is, nonetheless, chronologically subsequent to the church of equals. Paul's affirmation that 'There is neither Jew nor Greek, there is neither slave nor free, there is neither male nor female; for you are all one in Christ Jesus. And if you are Christ's, then you are Abraham's offspring, heirs according to promise' (Gal. 3:28-29) proclaims that, because the church is founded on Christ and on baptism, it has equality at its core. This truth is then expressed in the inter-relations that must characterise those who might claim leadership: the greatest is to be servant of all, ${ }^{50}$ and all are to relate in acts of mutual service. ${ }^{51}$ The title servus servorum Dei is a designation that every Christian needs to rejoice in, and in that is an implicit appeal to the covenantal relationship that exists with other disciples which is one of equality. ${ }^{2}$ For, within the Church we all children of the Father, ${ }^{53}$ and siblings to one another, as we proclaim within the liturgy. ${ }^{54}$

Being equal in the divine love that calls us into existence and in our calling to be disciples means that there is an equality in the work of the Spirit. The Spirit is active in every heart and mind allowing us to grasp the mystery of faith, and it is the Spirit which enables each to call out 'Abba! Father!' (Gal. 4:16)

49 See Samuel Laeuchli, Power and Sexuality: The Emergence of Canon Law at the Synod of Elvira (Philadelphia, PA: Temple University Press, 1972).

50 Mark 9:35 and 10:31 and parallels.

$5^{1}$ Mark 10:42-5 and parallels - and we should note that the foot washing in John is equivalent in its message.

$5^{2}$ By contrast, to view it as a uniquely papal title, or a title only applicable to someone in a special office, is to make it an act of condescension which implicitly affirms a relationship of inequality between superior and inferior.

53 The image of the disciples of Jesus as 'the children of God (huioi theou) through faith' (Gal. 3:26) is one that is found across the sweep of early documents: Rom. 8-9; Phil. 2:15; in the gospels (e.g. Matt. 5:9 or John 1:12); and in other early letters (e.g. it is used on three occasions in 1 John): it is an image that is fundamentally egalitarian among the children.

54 See Thomas O'Loughlin, Eating Together, Becoming One: Taking up Pope Francis's Call to Theologians (Collegeville, MN: Liturgical Press, 2019), pp. 33-46 which examines the value of using fictive familial language in creating new understanding of what we mean by 'church' today. And in connection with baptism, see Richard E. DeMaris, 'Backing Away from Baptism: Early Christian Ambivalence about its Ritual', Journal of Ritual Studies 27 (2013), pp. 11-19. 
in the midst of our sisters and brothers. The Spirit's presence acts as a 'leveller' within the church for without the Spirit we are not acting within the Christian mystery, and no matter how exalted some Christian might be in terms of ecclesiastical structures, that Christian should recall Paul's words:

To each is given the manifestation of the Spirit for the common good. To one is given through the Spirit the utterance of wisdom, and to another the utterance of knowledge according to the same Spirit, to another faith by the same Spirit, to another gifts of healing by the one Spirit, to another the working of miracles, to another prophecy, to another the ability to distinguish between spirits, to another various kinds of tongues, to another the interpretation of tongues. All these are inspired by one and the same Spirit, who apportions to each one individually as he wills

1 Cor. 12:7-11

While we experience liturgy as the most hierarchical - in both senses of the word - expression of the church (and this is true not just within the Roman Catholic Church, although its ritual spectacle is probably is the least expressive of an egalitarian vision of the baptised), and our ceremonies are often presented as paradigmatic examples of two-tier spectacle rituals, ${ }^{55}$ in its depths there is an affirmation of equality in a central place which tends to be obscured. Unlike the mystery religions of the Roman empire with complex levels of mysteries and initiation, Christianity has a single relatively simple ritual for women and men, poor and rich, for the distinguished and the slave: baptism. We have already quoted Paul on equality in baptism, but we should turn to the Didache - probably contemporary with him - for a statement of its simplicity, a ritual within reach of all:

With regard to baptism, here is the teaching:

You are to baptise in this way.

Once you have gone back over all that is in the Two Ways, you baptise in the name of the Father and of the Son and of the Holy Spirit in living water.

55 Spectacle rituals are built around the assumption that the doers / observers are not equally members of a community but in a binary relationship of suppliers / consumers; cf. Guy Debord, La société du spectacle (Paris: Buchet/Castel, 1967); on the prevalence of this notion of liturgy as a commodity to be consumed from its providers, see Thomas O'Loughlin, 'We are celebrants not consumers: CoviD-19 and the reappearance of transactionalism in Catholic liturgy', La Croix International 18 May 2020 at https://international.la-croix.com/ news/we-are-celebrants-not-consumers/12392 (Accessed 1 June 2021). 
However, if you do not have access to living water, then baptise in some other water; and if you do not have any cold water, then you can use warm water.

And if you cannot get access to either [running or still water], then pour water three times on the head in the name of the Father and of the Son and of the Holy Spirit.

Moreover, before the baptism takes place, let both the person baptising and the person who is going to be baptised fast - along with as many others as are able to do so. Indeed, you must instruct the person who is going to be baptised to fast for one or two days before the baptism

$7: 1-4^{56}$

There is no need to sacrifice a bull or throw a great feast for those already initiated; all you need is study, fasting, and some water. The liturgy of baptism brings it clearly home to the new disciple that the church is a community of equality - wealth and status should bring no special favour here. But, of course, we love gathering privilege around us, and this is what happened at the eucharistic meals in Corinth. ${ }^{57}$ The very problem that calls forth Paul's comments on the community meals of the Corinthian church is that the rich will not wait for the poor - and their practice does not express the equality of the members in the church. There have been endless 'corrections' of liturgical practice down to our own time, but Paul is more concerned that there should be equality around the eucharistic table. Poor and rich are one in their sharing; their common meal models the new creation. ${ }^{58}$ The foot washing in John 13:3-17 is a demonstration that mutual foot washing should remind each disciple of the equality that exists when you wash my feet and I wash yours. ${ }^{59}$ It is an act that

$5^{6}$ The translation is taken from Thomas O'Loughlin, The Didache: A window on the earliest Christians (London: SPCK, 2010), p. 166.

57 There is a large literature on the nature of the social differentiation with the community in Corinth that occasioned Paul's correcting criticisms; in the context of this paper's theme, see Rachel M. McRae, 'Eating with Honor: The Corinthian Lord's Supper in the light of Voluntary Association Meal Practices', Journal of Biblical Literature 130 (2011), pp. 165-181.

$5^{8}$ This point has been explored in many studies, but in our context, an appropriate paper is Robert Jewett, 'Gospel and Commensality: Social and Theological Implications of Gal. 2:14' in L. Ann Jarvis and Peter Richardson (eds), Gospel in Paul: Studies in Corinthians, Galatians, and Romans for Richard N. Longnecker (Sheffield: Sheffield Academic Press, 1994), pp. 240252. The theme's contemporary relevance is explored in Thomas O'Loughlin, The Eucharist: Origins and Contemporary Understandings (London: Bloomsbury, 2015), pp. 191-201.

59 Normally, both in the liturgy on Holy Thursday and in cultural memory (the Maundy traditions of many royal houses in Europe), this action is presented as the humility of the powerful towards their underlings: it is a ritual of condescension. However, the text of John 
is subversive of pyramids of privilege and power - and one that is markedly uncomfortable. ${ }^{60}$

Within the trinitarian dynamic of Christian life, the notion of equality has sound foundations. The Father's love is impartial and is with us in our creation, we become children of the Father in baptism, and 'we put on the Christ'61 whether we be male or female, Jew or Greek, slave or free. Having become sisters and brothers of Jesus - becoming a new fictive family of equals - we proclaim as one the death of the Lord for us all. And, in this new community, we are each brought to life in the Spirit, and the Spirit is poured out on each, enlightens each of us, and inspires us to stretch out our hands to the downtrodden, the needy, the sick, the imprisoned and the poor. ${ }^{62}$ One way to view the church is as God's movement for the promotion of equality in the universe.

\section{Equality as Part of Our Gospel}

The church is continually discovering new areas where its proclamation is a witness to the nature of God, the reality of the Christ-event, its duty of love to the human family and - especially in recent years - to the planet. What it means to witness to God's love is ever adapting to the reality in which we find ourselves. Thus, we discovered the need for social justice, the inherent injustice of the death penalty, and, most recently, ecology as a locus of theology. So, for the Roman Catholic Church, instead of just treating the human desire for equality as a part of modernity to be tolerated, or as a religiously neutral aspect of social change, the question arises whether it is a development that we should embrace within our kerygma? As Christians we do have a vision of human equality found in the Creator's love for all human beings, for all God children. To promote human fraternity witnesses to the nature of creation.

is clear: the example of Jesus is to be followed in that they all should wash each other's feet: in the mutual service there is the equality of the disciples so that there is none greater and none less. It is a perversion of the memory which interprets such a counter-cultural symbol of mutual service as one which preserves authority structures (that of king, bishop, or parish priest) under a show of top-down service. The context and implications are explored in Thomas O'Loughlin, Washing Feet: Imitating the Example of Jesus in the Liturgy Today (Collegeville, MN: Liturgical Press, 2015).

6o To see how the practice was subversive of top-down authority structures - and hence was modified to preserve inequality - see Janet M. Lindman, Bodies of Belief: Baptist Community in Early America (Philadelphia, PA: University of Pennsylvania Press, 2008).

61 Cf. Rom. 13:14 which is the image used in many early baptismal liturgies, and still in the liturgies of some churches today, of the newly baptised being clothed in a new garment.

62 Cf. Matt. 25:31-46. 
Likewise, we know we are sisters and brothers in Christ. So not to rejoice in, this vision of equality that is so widely desired by humans across our world is to fail to recognise that there is a continuity between nature and grace. Moreover, to make equality a core notion of our kerygma would provide a common language in which to profess our faith before humanity.

Equality is not merely an idea or a theory, it is a reality that can be felt, experienced, in human interaction, though it is most often conspicuous by its absence. One does not just 'believe in equality' but one acts in terms of equality, promotes equality, and defends equality, not only for others but for oneself. We need to develop a spirituality of equality; and the consistent challenging of human inequality must become a spiritual practice. ${ }^{63}$ Just as the cause of the abolition of the slave trade, then of slavery itself, became central to the spiritual identity of such men as William Wilberforce (178o-1825), the pursuit of human equality should be seen as a spiritual path of discipleship and witness. When the pursuit of equality is seen as a spiritual practice, Christians can see working for human equality in (e.g.) the removal of racism or gender bias as part of the fundamental vocation of the baptised whereby we witness to God's equal love of each person.

However, if this is to be part of Christian proclamation and a spiritual practice for individual Christians, then it must also be modelled explicitly by each church in its own life and liturgy. Looking at a church, one can see in its formal practices and structures the kind of life and values that it preaches. This is perhaps the most difficult area for the Roman Catholic Church where the issue of women's access to ministry is an area so fraught that many find even discussion impossible. Likewise, the issue of equality with regard to sexual orientation is a matter that some have considered closed. But the need to model a Christian vision of equality is in itself an argument for significant practical change in the Roman Catholic Church's guidance on Christian behaviour and in its own actions.

Christians should not, however, underestimate the difficulty of making changes as they uncover areas where their current practices project inequality - and where we may have been blind for centuries. Just as many organisations have to conduct training and self-critical audits regarding structural inequality,

63 Interestingly, some writers on social practice and equality argue that they should embrace the spirituality dimension of their endeavour (e.g., Bernard Moss and Neil Thompson, 'Spirituality and Equality', Social \& Public Policy Review 1.1 (2007), pp. 1-12; and Neil Thompson, 'Spirituality and Social Justice', in Darcy L. Harris (ed.), Handbook of Social Justice in Loss and Grief: Exploring Diversity, Equality, and Inclusion (New York: Routledge, 2016), pp. 191-201); my case here is that one should also link with social equality from a starting point within spirituality. 
so will each church. While everyone may acknowledge the difficulties that are involved in relation to women and ministry, which is presented officially as having a basis within divine revelation, for the Roman Catholic Church equality embraces a raft of other areas from its use of titles that imply a hierarchy of status vis-à-vis one another within the church, or vestments and vesture that highlight distinctions of rank, and patterns of deference derived from courtly structures that may prove just as painful and as difficult to address. It belongs to the human condition that equality goes against the grain. The natural ambition to get one step higher than the person next to us is part of the existential situation that we challenge with the grace of the gospel. Likewise, inherited structures - such as a male-only presbyterate - always take on a sacral aura as if they are grounded in the divine will.

\section{Synodality}

Until quite recently 'synodality' was a notion that only had a place in the ecclesiology of the Eastern Churches where it affirmed that a patriarch was not a pope (in the sense of the Bishop of Rome), but that bishops acted together as a community of equals with the patriarch as a primus inter pares. In some of these churches the challenge was then for the bishop to act in a synodal way with his presbyters. It has also been a part of modern Anglican ecclesiology where synodical government is a highly structured quasi-parliament of three 'estates': the House of Bishops, the House of Clergy, and the House of Laity. ${ }^{64}$ But for Roman Catholics synodality is not only a new notion but even a new language. ${ }^{65}$ One of the few things that all are agreed upon is that whatever it means will only be discovered in the messy process which we are only now beginning. At one extreme it is seen as the form that representative democracy takes within the church, while, at the other extreme, there is a belief that it is merely an exercise in window dressing to assuage criticisms in some developed western liberal societies. Most seem to imagine that it is somewhere between these positions and that one has to sail carefully in uncharted waters!

One other matter seems clear: there will be many discussions of what is meant by equality - and its importance in the Roman Catholic Church - in

64 See https://www.churchofengland.org/about/leadership-and-governance/about-generalsynod (Accessed 21 August 2021).

65 Hence the exploration of the term which forms the opening sections of the International Theological Commission's report. 
the months and years ahead. ${ }^{66}$ Moreover, these debates will not be resolved by an appeal to notions such as 'apostolic authority', or that 'the church is not a political entity', or slogans masquerading as theological principles such as 'the church is not a democracy'. All such sound-bites seem to anyone with a different perspective as little more than justifications of the status quo. Virtually every person who takes part will have grown up in a society where equality of treatment and of opportunity is, at the very least, claimed as a human goal; where there will be a degree of equality of education that is unparalleled in human history and with such equality runs an equality of expectation; and the notion that one only takes part to the extent that one is represented (the slogan: 'No taxation without representation' of some of the English colonies in the Americas in 1775) is now an assumption in almost every organisation to which those Roman Catholics engaged with synodality belong. Moreover, no matter how it is approached, synodality calls for mutual recognition of participants as peers. In the light of the forthcoming synod, George Wilson has given a useful equivalent for synodality in the term 'sharing responsibility'; but, at once, he noted that there is an implicit appeal to equality in this approach because the 'coming together' in a synod (the original meaning of 'synod') 'involves the coming together of human peers.'

A synodal body will ordinarily be composed of people from different strata in the organization: various office holders, past officers, significant community members, people with demonstrated talents in other organizations. All well and good. But once in operation, each member should, in theory, be accorded the same hearing as every other. That principle holds true no matter [what] the criteria by which members were originally selected. That reasonable expectation of synodal equality is destroyed when the process of decision-making reveals that some participants are listened to while the voice of others is muted. ${ }^{67}$

If this sense of being peers in responsibility within the church is once achieved, it ushers in a church-experience of shared responsibility among the baptised. And once that has been set behind us, we must carve out new ways of being local churches, diocesan and regional churches, a world-wide church which

66 This has barely begun in English, but in German the number of papers on synodality has grown exponentially in the past five years.

67 George Wilson, 'Synodality: A Welcome Concept, but difficult to achieve,' La Croix International 27 May 2021. Available at https://international.la-croix.com/news/religion/ synodality-a-welcome-concept-but-difficult-to-achieve/14380 (accessed 1 June 2021). 
looks to the Bishop of Rome as an instrument of our unity in some way or other, and to the still more varied ecumenical reality: the church of Christ.

Rather than a self-defeating squabble about what 'equality' within the Roman Catholic Church (whose status as a promoter of human dignity is only as great as the most recent scandal about church institutions, such as the Magdalen Laundries in Ireland) ${ }^{68}$ means (for its meaning is amply understood within democratic cultures) we should now openly embrace it. Equality is not an alien 'secular concept' imported into where it has no proper place, but an inherent part of our Christian vision. Indeed, if Roman Catholics do not grasp the vision of the promotion of human equality as a theological principle, then any real advance towards a synodal ecclesiology, much less a synodal church, may be illusory.

How should we embrace it? There is no finer model of equality than the equality of service as found in John 13:3-17. As the Lord and took on the role of the lowliest female household slave in relation to those whom he will soon address as 'friends' (John 15:13-5) - friendship being the paradigm of equality within the ancient world, ${ }^{69}$ so we can all adopt this attitude in affirmation of our mutual equality as the baptised and as pilgrims. Whatever may have happened in the history of the Roman Catholic Church or of any other church, we should recall that we are not followers of some authoritative blueprint for faith, order, or organisation, but a community called in the Spirit to be conformed to the person, work and character of Jesus Christ which is the heart of the gospe $\mathrm{l}^{70}$ and that this demands proclaiming that human equality is a basic element of our vision. But as that foot washing by Jesus provoked 'push back' in the Johannine story, we should not expect this development to be a straight path. ${ }^{71}$

68 Cf. Thomas O'Loughlin, 'The Credibility of the Catholic Church as a Public Actor', New Blackfriars 94 (2013), pp. 129-147.

69 Cf. Malcolm Schofield, 'Political Friendship and the Ideology of Reciprocity', in Paul A. Cartledge, Paul Millet, and Sitta von Reden (eds), Kosmos: Essays in Order, Conflict and Community in Classical Athens (Cambridge: Cambridge University Press, 1998), pp. 37-51.

70 Cf. Rom. 12:2; and see Avis, 'The Paschal Mystery', p. 6.

71 I wish to thank both anonymous reviewers for their insightful comments that has resulted in a much better paper; for the faults that remain, I alone am responsible. 